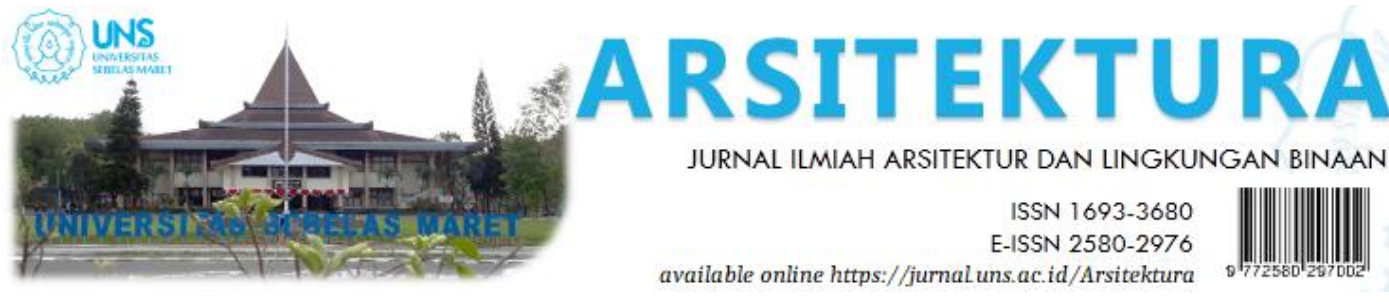

Volume 18 Issue 1 April 2020, pages:74-83

\title{
Studi Pengaruh Gaya Arsitektur Bangunan Terhadap Daya Tarik Kunjungan Wisata di Kota Lama Semarang
}

\section{Studi of Building Architecture Style Effect on Tourism Attractions in The Old City of Semarang}

\author{
Agus Heru Purnomo ${ }^{1 *}$, Sumaryoto $^{2}$, Suparno $^{3}$ \\ Program Studi Arsitektur, Fakultas Teknik, Universitas Sebelas Maret ${ }^{{ }^{*}}$ \\ Email: herupurnomo35@gmail.com \\ Program Studi Arsitektur, Fakultas Teknik, Universitas Sebelas Maret $^{2}$ \\ Program Studi Arsitektur, Fakultas Teknik, Universitas Sebelas Maret ${ }^{3}$
}

DOI: https://doi.org/10.20961/arst.v18i1.36214

Received: December 2, 2019 Revised: March 21,2020 Accepted: March 21,2020 Available online:April 30,2020

\begin{abstract}
Tourism is one of the creative industries that bring substantial benefit to the country, therefore it is necessary to explore and map new potential sources in the field for tourism. Most cities in Indonesia has the opportunity to be developed into a tourist city, this can be seen from several components that can be used as a tourist attraction of a city. The components that can be an attraction include: a city area that is historically area with unique architectural style. Urban tourism potential that can be used as a superior tourism product, it requires integration of related 4 (four) aspects: tourist attractions, transportation aspects, and supporting facilities, and institutional aspects. The city of Semarang is the capital of Central Java which has a number of objects and tourist attractions that are quite diverse, including: the Old City area of Semarang is an area of 31 hectares that has a number of ancient buildings of historical value with the style of Colonial Architecture. The old city area of Semarang, known as "Little Netherlands". is a conserved area and now being reorganized to be a world tourist destination. The purpose of this study was to conduct a study of the influence of architectural styles on the attractiveness of tourist visits in the Old City area of Semarang. To be able to achieve the objectives of this study, the research method used is qualitative-rationalistic. The resulst of the study that the architectural style in the old city of Semarang is very influential on tourist attractions, especially those that have elements of classical European architecture, Renaissance, Baroq, and a blend of local elements, namely The Indisce Empire Style.
\end{abstract}

Keywords: Tourist Attraction, Architectural Style, Semarang Old City

\section{PENDAHULUAN}

Perkembangan industri pariwisata saat ini menunjukkan adanya peningkatan yang sangat pesat sehingga mendorong berbagai negara di dunia untuk berkompetisi memperoleh devisa dari sektor kepariwisataan. Sektor pariwisata merupakan sumber penghasil devisa yang cukup prospektif dan merupakan harapan baru untuk dapat menggantikan sumber devisa dari komoditas lainnya yang semakin melemah. Di samping itu, ancaman krisis ekonomi global juga semakin mendorong mereka untuk 
memprioritaskan pembangunan sektor pariwisata sebagai upaya untuk mewujudkan peningkatan disektor ekonomi. Dalam perkembangan selanjutnya ternyata pariwisata juga menjadikan setiap negara saling terhubung dalam jejaring industri pariwisata internasional, oleh karena itu perlu dilakukan upaya untuk menjadikan pariwisata sebagai sebuah bisnis internasional yang memberikan manfaat yang signifikan untuk Negara.

Pembangunan di bidang kepariwisataan merupakan pembangunan yang terintegrasi dari beberapa aspek yang diharapkan dapat mewujudkan keberhasilan dan kepuasan untuk semua pihak. Sebagaian besar kota-kota di Indonesia sangat berpotensi untuk dapat dikembangkan sebagai kota wisata dengan berbagai potensi yang dimilikinya. Hal ini dapat dilihat dari beberapa obyek yang dapat menjadi daya tarik sebuah kota antara lain adalah: kawasan kota yang bermakna historis, budaya, kuliner khas kota, pasar tradisional, alun-alun, taman kota, museum kota, dan sebagainya.

Kawasan kota lama Semarang merupakan kawasan yang memiliki bagian sejarah masa lalu pada jaman pemerintahan Hindia Belanda di Indonesia, yang sampai sekarang masih terdapat peninggalan beberapa bangunan kuno yang berdiri dengan megah pada kawasan bagian utara kota Semarang tersebut. Peninggalan sejumlah bangunan kuno dengan gaya (style) arsitektur kolonial dan Eropa klasik merupakan artefak bernilai sejarah dan arsitektur yang tinggi. Bangunan-bangunan dengan gaya arsitektur kolonial merupakan ciri khas yang ada pada kawasan kota lama ini, meskipun sekarang kondisinya sebagian sudah rusak karena tidak terawat dengan baik. Kawasan kota lama Semarang yang dikenal dengan " Little Netherlands " merupakan kawasan yang dikonservasi berdasarkan Peraturan Daerah Nomer 8 tahun 2003, Kawasan Kota Lama Semarang merupakan warisan sejarah pertumbuhan kota Semarang yang memiliki nilai arsitektural, ilmu pengetahun dan budaya yang tinggi sehingga perlu dilestarikan dan ditata kembali secara terarah untuk menyesuaikan dengan kebutuhan dan perkembangan jaman. Dalam upaya melestarikan, menata dan menghidupkan kembali kawasan Kota Lama Semarang agar lebih terarah dalam pertumbuhan dan pembangunannya, maka disusunlah Rencana Tata Bangunan dan Lingkungan (RTBL) Kawasan Kota Lama Semarang. Kota Lama Semarang yang terletak di Kelurahan Bandarharjo, kecamatan Semarang Utara. Batas Kota Lama Semarang dibatasi oleh: sebelah Utara Jalan Merak dan stasiun Tawang, sebelah Timur berupa Jalan Cendrawasih, sebelah Selatan adalah Jalan Sendowo dan sebelah Barat berupa Jalan Mpu Tantular dan sepanjang sungai Semarang. Luas kawasan Kota Lama Semarang sekitar 0,3125 $\mathrm{km}^{2}$. Dalam rangka penataan kawasan kota lama semarang maka masyarakat berhak untuk:

a. Berperan serta dalam proses perencanaan, pemanfaatan dan pengendalian.

b. Mengetahui secara terbuka RTBL Kawasan Kota Lama Semarang.

c. Menikmati manfaat kawasan dan atau pertambahan nilai kawasan (sosial, budaya, ekonomi dan edukasi) sebagai akibat dari adanya penataan kawasan tersebut. (Pasal 55, Perda. No. 8 Tahun 2003).

Oleh karena itu kegiatan penelitian ini merupakan bagian dari peran serta masyarakat dalam proses perencanaan, pemanfaatan dan pengendalian kawasan kota lama Semarang.

Karya Arsitektur merupakan arkeologi masa depan yang menghubungkan sejarah masa lalu, sekarang dan yang akan datang (Eko Budiharjo, 1997) dalam konteks ini, maka upaya konservasi di kawasan tersebut adalah sangat tepat karena bangunan-bangunan bersejarah dengan nilai Arsitektur yang tinggi terdapat di kota lama Semarang, antara lain adalah: bangunan Gereja Blenduk / gereja Immanuel yang didirikan pada tahun 1753 oleh arsitek Belanda H.P.A. De Wilde en W. Westmaas merupakan gereja pertama yang dibangun di kota Semarang yang kemudian direnovasi pada tahun 1894-1895, gedung kantor Asuransi Jiwa Sraya dibangun tahun 1925 oleh arsitek Thomas Herman Karsten, Gedung Marba, Gedung Spiegel, Kantor PT. Perusahaan Perdagangan Indonesia, Bank Mandiri dan sebagainya (Bappeda Kota Semarang). Dengan adanya bangunanbangunan bersejarah dengan nilai Arsitektur yang tinggi tersebut ditengarai menjadi potensi daya tarik wisata yang ada pada 
kawasan Kota Lama Semarang. Oleh karena itu peneliti perlu melakukan pembuktian berupa langkah penelitian mengenai potensi daya tarik wisata di kota lama Semarang dengan judul: "Studi pengaruh gaya Arsitektur bangunan terhadap daya tarik kunjungan wisata di kawasan kota lama semarang".

\section{METODE}

Metode penelitian yang diterapkan pada penelitian ini adalah: berpedoman pada aspek yang dapat membentuk keindahan dan kualitas estetika, dimana nilai-nilai dari bentuk dan ekspresi yang nampak secara visual dapat "menyenangkan mata dan pikiran". (Nurmasari, 2008:20)

Dari pemahaman teori tersebut maka daya tarik yang ada pada lokasi penelitian adalah berupa obyek visual yang dapat menyenangkan mata dan pikiran dan berupa fisik bangunan yang indah dan memiliki kualitas estetika, yaitu berupa bangunanbangunan peninggalan kolonial Belanda. Gedung-gedung yang ada di kota lama Semarang pada kenyataanya merupakan suatu bangunan yang mempunyai persamaan gaya arsitektur yang bercorak Indische Empire Style mirip dengan yang ada di Eropa. Arsitektur dengan gaya seperti Renaissance, Barok, Rokoko dan Empire dalam pemakaian ragam hias atau ornamen memegang peranan sangat besar, dan sangat memperhatikan unsur "estetika, keseimbangan dan harmoni" (berpedoman pada kaidah Teori Renaissance). Dengan mengembangkan rasio-rasio tersebut tidak hanya pada dimensi sebuah ruang atau façade, tetapi juga di dalam proporsi suatu ruang atau suatu denah. Adapun teori "Balance", mengemukakan tentang keseimbangan dalam bentuk, dimensi dan rasio. Hal ini mengacu pada falsafah yang dibuat oleh "Plato, Pythagoras dan Aristoteles". Teori Plato melihat bahwa keindahan alami muncul melalui adanya garis, lingkaran, dan permukaan yang menghasilkan bentuk dan volume geometris yang absolut. Teori Pythagoras merupakan dasar pengembangan rasio perbandingan yang membentuk dasar bagi proporsi-proporsi arsitektural dengan mencoba perhitungan matematis untuk membentuk suatu yang "Estetis". (Tjahyono Gunawan, 1999)
Dengan berpedoman pada teori formal tersebut maka peneliti melakukan langkah penelitian awal untuk mengidentifikasi dan menentukan bangunan-bangunan tertentu yang ada pada lokasi penelitian yang menurut persepsi peneliti (Arsitek) memenuhi kreteria tersebut. Sehingga hasilnya adalah obyek bangunan 1 sampai 9 (obyek 1-9) yang nantinya akan ditanyakan kepada responden/ pengunjung.

Adapun beberapa aspek yang terkait dengan metode penelitian ini adalah: lokasi dan waktu penelitian, sumber data dan teknik pengambilan data, teknik pengolahan data dan teknik analisis data. Metode penelitian yang digunakan dalam penelitian ini adalah kualitatif-rasionalistik.

\subsection{Lokasi Penelitian}

Penelitian ini berlokasi di Kawasan Kota Lama Semarang, dengan batas-batas sebagai berikut:

- Sebelah Utara adalah Jalan Merak dan Stasiun Tawang.

- Sebelah Timur adalah Jalan Cendrawasih.

- Sebelah Selatan adalah Jalan Sendowo Barat dan Timur.

- Sebelah Barat adalah Jalan Mpu Tantular dan Kali Semarang.

Luas Kawasan Kota Lama Semarang kurang lebih $31 \mathrm{Ha}$ dengan batas-batas fisik dapat dilihat pada peta dibawah ini.

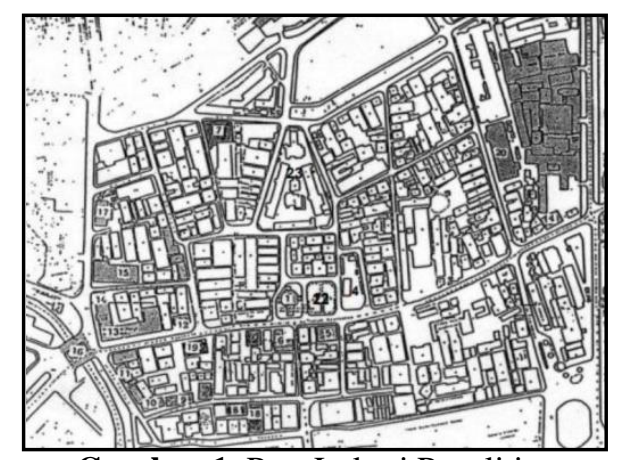

Gambar.1 Peta Lokasi Penelitian

(Sumber: Bappeda Kota Semarang)

\subsection{Pengumpulan dan Pengolahan Data}

Teknik pengumpulan data yang digunakan pada penelitian ini adalah survei lapangan dan observasi yakni pengumpulan data secara langsung dengan pengamatan maupun perekaman foto, baik yang diambil oleh peneliti sendiri maupun foto yang diambil oleh orang lain. (Bogdan dan Biklen, 1982:102). 
Pengumpulan data primer juga dilakukan dengan cara wawancara terstruktur dengan reponden yang dipilih secara purposif. Data sekunder didapat dari laporan, catatan tertulis dan jurnal yang tersedia di Dinas Pariwisata Kota Semarang, serta sumber elektronik lainnya yang berasal dari website Dinas Pariwisata dan Kementerian Pariwisata. Data sekunder digunakan untuk memperkuat informasi atau ferifikasi data yang telah didapat dari sumber data primer. Data yang terkumpul dari hasil observasi obyek Gaya Arsitektur yang menjadi daya tarik wisata dikelompokkan dan diberi kode tertentu untuk selanjutnya dianalisis. Adapun data hasil wawancara dengan responden merupakan hasil persepsi responden/ pengunjung terhadap obyek yang diamati (what to see) yang disampaikan kepada peneliti lewat Pertanyaan/questioner. Jenis pertanyaan yang diajukan kepada responden dirancang menurut Patton (1980: 207-211) pertanyaan yang diajukan oleh pewawancara/peneliti kepada responden ada 6 (enam) jenis pertanyaan, 3 (tiga) diantaranya adalah:

a. Pertanyaan yang berkaitan dengan perasaan

b. Pertanyaan yang berkaiatan dengan indera.

c. Pertanyaan yang berkaitan dengan pendapat.

Pada penelitian ini pertanyaan yang peneliti ajukan pada responden adalah pertanyaan yang berakaitan dengan indera visual, pendapat dan perasaan yang dihubungkan dengan kemenarikan obyek bangunan gedung yang sedang diamati.

Untuk mendapatkan hasil respon dari obyek yang diamati sebagai data "Ordinal", maka jawaban responden merupakan respon terhadap kemenarikan obyek yang sedang diamati. Jawaban responden dirancang sedemikian rupa sehingga jawabannya dapat dikuantifikasikan secara sederhana dalam skala Likert. Metode ini dilakukan untuk mengetahui besarnya frekuensi dan bobot nilai dari hasil persepsi responden/pengamat terhadap ketertarikannya pada obyek yang diamati. Data dari observasi peneliti (Arsitek) di lapangan merupakan langkah inventarisasi/ penelitian awal yang selanjutnya di identifikasi dan dibahas secara deskriptif dilengkapi dengan gambar/foto kemudian dibuat kategorisasi. Kreteria Pemilihan Obyek (1-9) mengacu pada teori formal Arsitektur.

\subsection{Analisis Data}

Metode analisis dalam penelitian ini menggunakan pendekatan KualitatifRasionalistik yang dipadukan dengan pendekatan kuantitatif, dimana data kualitatif (persepsi responden) dirancang sebagai data ordinal kemudian di kuantifikasikan dengan skala Likert, yaitu data responden yang berupa data persepsi ketertarikan responden terhadap obyek (Bangunan) yang kemudian dibuat Tabulasi Data untuk tujuan pembobotan nilai terhadap Obyek (Bangunan) yang sudah diamati secara visual oleh responden. (Y. Slamet, 1993, hal: 6-15).

Dalam metode analisis ini peneliti menggabungkan dua pendekatan kualitatif dan kuantitatif, untuk tujuan memperkuat kesahihan temuan-temuan. (Julia Brannen, 1996, hal: 84-85).

Pengukuran dari persepsi responden adalah sebagai berikut:

Tolok Ukur Kemenarikan: Nilai (4) $\underline{\text { sangat }}$ menarik, misalnya peristiwa/kondisi alam yang sangat mengagumkan dan menakjubkan atau kekayaan/nilai-nilai budaya yang tinggi dan artefaknya, semua orang secara umum akan mengaguminya (berpendapatan sama). Nilai (3) menarik, peristiwa/kondisi alam atau kekayaan/nilai-nilai budaya yang sangat mengagumkan bagi sebagian orang yang memiliki ketertarikan pada obyek dan memiliki nilai edukatif. Nilai (2) tidak menarik, tidak menimbulkan rasa kagum, nyaman, senang, dan tidak mendorong munculnya rasa ingin tahu. Orang tidak terlalu peduli dengan daya tarik yang ditawarkan. Nilai (1) sangat tidak menarik, orang tidak sedikit pun memiliki keinginan untuk mengunjungi daya tarik wisata ini karena kondisinya yang sudah rusak atau tidak mengandung nilai rekreatif atau edukatif.

Data persepsi dari responden diambil sebanyak 20 orang yang dipilih secara purposive berupa jawaban dari daftar Pertanyaan yang dibuat berkaitan dengan respon indera visual dan perasaan responden terhadap kemenarikan/ ketertarikan terhadap obyek fisik yang diamati dan dirasakan (what to see) berupa bangunan 
dengan gaya Arsitektur tertentu. Pertanyaan diajukan dengan wawancara terstruktur secara langsung kepada responden, yang intinya ingin mengetahui persepsi ketertarikan responden terhadap obyek visual (bangunan gedung dengan gaya Arsitektur tertentu) yaitu Obyek 1-9, yang dipilih oleh peneliti berdasarkan kaidah teori arsitektur dari aspek estetika/keindahan pada facade bangunan (mengacu pada kaidah teoritik).

\section{HASIL DAN PEMBAHASAN}

Menurut Patton (1980: 207-211) pertanyaan yang diajukan oleh pewawancara/peneliti kepada responden ada 6 (enam) jenis pertanyaan, 3 (tiga) diantaranya adalah:

a. Pertanyaan yang berkaitan dengan perasaan b. Pertanyaan yang berkaiatan dengan indera. Pertanyaan yang berkaitan dengan pendapat.

Pada penelitian ini pertanyaan yang peneliti ajukan pada responden adalah pertanyaan yang berakaitan dengan indera visual, pendapat dan perasaan yang dihubungkan dengan kemenarikan obyek bangunan gedung yang sedang diamati.

Jawaban dari pertanyaan yang diajukan kepada responden akan dikategorikan menjadi 4 (empat) tingkatan, yaitu: 1). Sangat Menarik, nilainya $=4,2$ ) Menarik nilainya $=3,3$ ) Tidak Menarik nilainya $=2$, 4) Sangat Tidak Menarik nilainya $=1$

Tabel. 1 Tingkat Kemenarikan Obyek 1-9

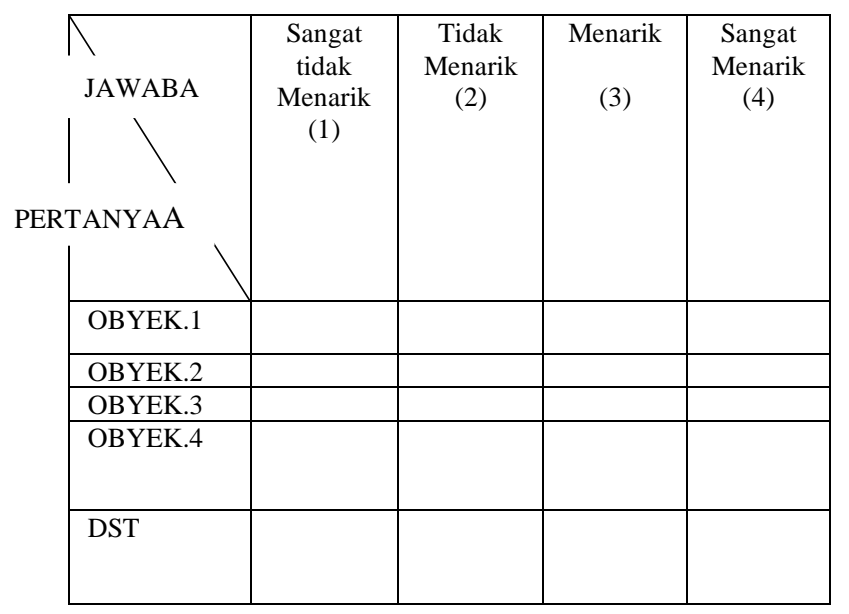

Menghitung bobot nilai Kemenarikan (Nilai Respon) setiap responden terhadap obyek visual yang diamati (Obyek 1-9) dan Skore Nilai Obyek (Rangking).

Tabel. 2 Perhitungan Responden Dan Rangking Obyek 1-9

\begin{tabular}{|c|c|c|c|c|c|c|c|c|c|c|}
\hline \multirow{2}{*}{$\begin{array}{c}\text { No } \\
\text { Respon } \\
\text { den }\end{array}$} & \multicolumn{9}{|c|}{$\begin{array}{l}\text { Pertanyaan } \\
\text { (Obyek 1-9) }\end{array}$} & \multirow{2}{*}{$\begin{array}{c}\text { Juml } \\
\text { ah } \\
\text { Nilai } \\
\text { Resp } \\
\text { on }\end{array}$} \\
\hline & 1 & 2 & 3 & 4 & 5 & 6 & 7 & 8 & 9 & \\
\hline 1 & 4 & 4 & 4 & 4 & 4 & 3 & 4 & 3 & 4 & 34 \\
\hline 2 & 4 & 4 & 3 & 4 & 4 & 3 & 4 & 4 & 3 & 33 \\
\hline 3 & 4 & 4 & 4 & 4 & 4 & 2 & 4 & 4 & 3 & 33 \\
\hline 4 & 4 & 3 & 4 & 4 & 4 & 2 & 4 & 4 & 3 & 32 \\
\hline 5 & 4 & 4 & 4 & 4 & 4 & 3 & 4 & 4 & 3 & 34 \\
\hline 6 & 4 & 4 & 4 & 3 & 4 & 3 & 4 & 4 & 3 & 33 \\
\hline 7 & 4 & 4 & 4 & 4 & 4 & 4 & 3 & 4 & 4 & 35 \\
\hline 8 & 4 & 4 & 4 & 4 & 4 & 3 & 4 & 3 & 3 & 33 \\
\hline 9 & 4 & 4 & 4 & 3 & 4 & 2 & 4 & 3 & 4 & 32 \\
\hline 10 & 4 & 4 & 4 & 4 & 3 & 4 & 4 & 3 & 3 & 33 \\
\hline 11 & 4 & 4 & 4 & 4 & 4 & 4 & 4 & 3 & 3 & 34 \\
\hline 12 & 4 & 4 & 4 & 4 & 4 & 3 & 3 & 2 & 4 & 32 \\
\hline 13 & 4 & 4 & 4 & 4 & 4 & 3 & 4 & 3 & 3 & 33 \\
\hline 14 & 4 & 3 & 4 & 4 & 4 & 2 & 4 & 4 & 4 & 33 \\
\hline 15 & 4 & 4 & 4 & 4 & 3 & 3 & 4 & 3 & 4 & 33 \\
\hline 16 & 3 & 4 & 3 & 4 & 3 & 3 & 4 & 2 & 4 & 30 \\
\hline 17 & 4 & 3 & 4 & 4 & 4 & 3 & 3 & 2 & 4 & 31 \\
\hline 18 & 4 & 3 & 4 & 3 & 4 & 3 & 4 & 4 & 4 & 33 \\
\hline 19 & 4 & 4 & 3 & 4 & 4 & 3 & 4 & 4 & 3 & 33 \\
\hline 20 & 4 & 4 & 3 & 4 & 4 & 3 & 4 & 4 & 4 & 34 \\
\hline Rangkin & 7 & 7 & 7 & 7 & 7 & 5 & 7 & 6 & 7 & \\
\hline $\begin{array}{c}\mathbf{g} \\
\text { Obyek }\end{array}$ & 9 & 6 & 6 & 7 & 7 & 9 & 7 & 7 & $\mathbf{0}$ & \\
\hline
\end{tabular}

Range $=35-30=5$

Interval Kelas $=(5+1): 2=3$

Kategori Responden/jumlah kelas: 2

Tidak Menarik $=$ Nilai $30 \mathrm{~s} / \mathrm{d} 32$

Menarik = Nilai $33 \mathrm{~s} / \mathrm{d} 35$

Hasil/jumlah nilai persepsi responden terhadap obyek yang diamati adalah sebagai berikut:

Tabel. 3 Tabulasi Frekuensi:

\begin{tabular}{|l|c|}
\hline \multicolumn{1}{|c|}{ Kategori } & Frekuensi \\
\hline $\begin{array}{l}\text { Tidak Menarik } \\
\text { (nilai=30-32) }\end{array}$ & 5 \\
\hline $\begin{array}{l}\text { Menarik } \\
\text { (nilai=33-35) }\end{array}$ & 15 \\
\hline Jumlah & $\mathbf{2 0}$ \\
\hline
\end{tabular}

Obyek yang tidak Menarik $=5 / 20 \times 100 \%$ $=25 \%$

Obyek yang Menarik $=15 / 20 \times 100 \%$ $=75 \%$ 
a. Gereja Imanuel / Gereja Blenduk (Obyek.1)

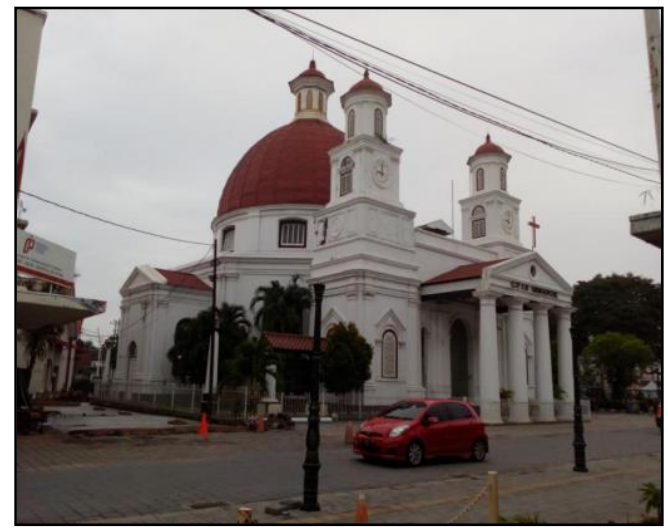

Gambar 2. Gereja Imanuel

Gereja Blenduk / gereja Immanuel yang didirikan pada tahun 1753 oleh arsitek Belanda H.P.A. De Wilde en W. Westmaas merupakan gereja pertama yang dibangun di kota Semarang yang kemudian direnovasi pada tahun 1894-1895. Facade bangunan menjadi elemen Streetscape pada jalan Letjen Suprapto (Heerenstraat) dan juga sebagai Tengeran utama pada kawasan pusat kota lama Semarang, dimana lay-out bangunan gereja ini berdiri sendiri " free standing " diantara setting bangunan lain yang ada di sekitarnya. Gereja Blenduk dibangun untuk pertama kali dengan nama "De Nederlandsche Indische Kerk. Di samping gereja (sebelah timur) terdapat enclosed square ('Taman Srigunting") yang berfungsi sebagai taman kota. Hal ini mengingatkan kita pada konsep Camillo Site,1889 (The Piazza del Duomo dengan gereja yang free standing) tentang fungsi square di abad pertengahan yaitu untuk kehidupan masyarakat berkomunitas di ruang terbuka (dalam R. Collins, 1986:154) Obyek visual gereja ini merupakan Symbolic Image yang sekaligus sebagai " Focal Point " atau "Landmark". Taman Srigunting pada zaman kolonial memiliki fungsi sejarah sebagai parade plein untuk panggung parade. Bangunan Gereja Blenduk dan Taman Srigunting merupakan bagian jantung koridor Jl. Letjen Soeprapto, dimana bangunan Gereja memiliki facade yang khas berupa atap dome, Pada facade bangunan terdapat deretan kolom dengan kepala dihiasi elemen dekoratif bermotif Ionic, pediment, cornice-molding, Jendela Glass in Lood yang dibuat mosaik yang sering disebut "vitrum" dan ada menara disisi kiri dan kanan, sehingga mencirikan gaya Arsitektur Renaisance, Arsitektur bangunan pada masa Renaissance yang memiliki fungsi keagamaan seperti "Gereja dan Kapel”, bangunan-bangunan istana, pusat pemerintahan dan rumah-rumah kediaman pendeta atau saudagar (merupakan anggota masyarakat yang terhormat) memiliki karakteristik yang menonjol pada bangunan tersebut antara lain adalah : Penerapan konsep simetri yang kuat, pada tampak dan ruang dalam bangunan. Mayoritas pemakaian bahan bangunan/material pada interior dan warna bangunan yang cenderung monochrome atau satu warna. Bangunan Gereja Blenduk ini kaya akan elemen dekoratif berupa cornice dan molding, baik pada interior maupun eksterior bangunan, namun bila kita lihat secara detail ornament dan elemen arsitektur pada bagian interior maka sangat jelas menggunakan langgam "Pseudo Baroque".

\section{b. Kantor Asuransi Jiwa Sraya (Obyek.2)}

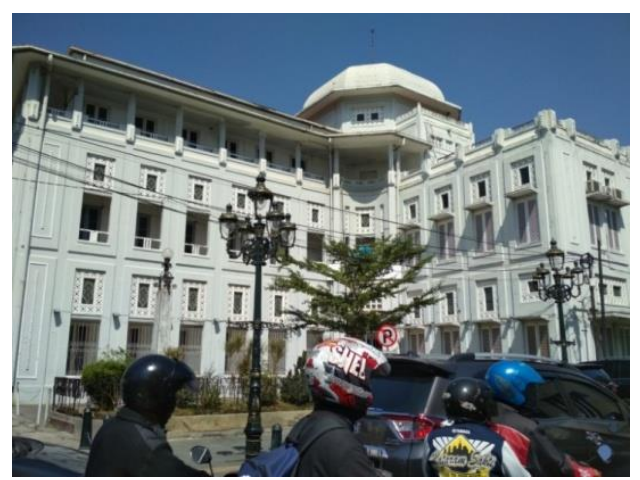

Gambar 3. Kantor Asuransi Jiwa Sraya

Kantor Asuransi Jiwa Sraya dibangun pada tahun 1925 oleh arsitek Thomas Herman Karsten. Kantor ini masih berfungsi dengan baik dan fisik bangunan terpelihara, sehingga Fasade bangunan memberi kontribusi terciptanya Streetscape pada koridor jalan Letjen. Suprapto. Gaya arsitektur indis yang nampak ditandai dengan volume bangunan yang berbentuk kubus, gavel horizontal, atap datar dan kubah serta didominasi oleh warna putih sebagai cirinya. Detail ornament menggunakan rooster dan kisi-kisi beton berbentuk bujur sangkar. Adanya selasar depan dan balkon adalah upaya untuk mengatasi iklim tropis. Secara keseluruhan 
bangunan kantor Jiwa Sraya ini merupakan suatu bangunan yang mempunyai persamaan gaya arsitektur yang bercorak Indische Empire Style.

\section{c. Gedung Marba (Obyek.3)}

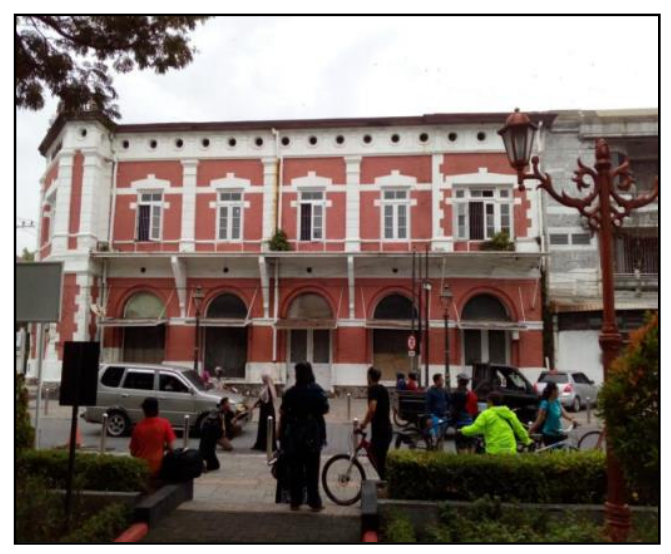

Gambar 4. Gedung Marba

Gedung Marba (Marta Badjunet), Bangunan ini di fungsikan untuk rumah makan di lantai.1 dan fisik bangunan terpelihara, sehingga Facade bangunan memberi kontribusi pada terciptanya Streetscape yang spesifik pada koridor jalan Letjen. Suprapto.

Gordon Cullen, 1961, menjelaskan bahwa "see on detail", aspek ini merupakan eksplorasi petualangan visual Cullen untuk menemukan esensi dari gaya Arsitektur tertentu yang berpengaruh pada kualitas obyek visual. See on detail akan bermakna sebagai surface-face (wajah), dalam konteks ini wajah jalan adalah sederetan dinding bangunan yang membentuk koridor yang sejajar dengan sumbu jalan. Facade (face on the street walls), Face (wajah) merupakan obyek visual yang mudah dikenali dan spesifik sehingga mudah untuk diingat (mental image). See on detail dapat untuk mengenali obyek dengan cermat dan teliti mengenai: bentuk, ragam, gaya, warna, teksture dan material, sehingga obyek visual tersebut dengan mudah dapat dikenali karakter dan gaya Arsitekturnya. Gaya The Empire Style pada Gedung Marba, dicoba untuk disesuaikan dengan iklim di Semarang. Hasilnya merupakan gaya arsitektur yang khas bentuk fasade didominir oleh hiasan berbentuk "Vousoir" diatas jendela pada tampak depannya, tower pada pintu masuk diatasnya dihiasi dengan tympanum, serta detail-detail eksterior dan interior yang teliti warisan gaya Art and Craft yang dianut oleh banyak pengikut PJH. Cuypers di Belanda.

\section{d. Kantor Bank Mandiri (Obyek.4)}

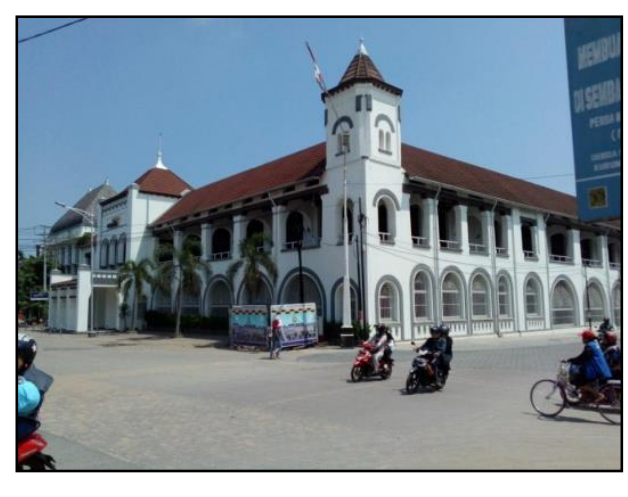

Gambar 5. Bank Mandiri

Kantor Bank Mandiri (dulu Nederlandsche Handel-Maatschappij, 1915) masih berfungsi dengan baik dan fisik bangunan terpelihara, sehingga Facade bangunan memberi kontribusi sangat baik pada terciptanya Streetscape yang spesifik pada koridor jalan Empu Tantular. Bangunan Bank Mandiri KCP Mpu Tantular memiliki beberapa ornamen pembentuk facade bangunan berbentuk geometrik sederhana pada facade dibentuk dari vousoir berbentuk lengkung dengan molding sederhana pada lantai 1 bangunan. Gaya The Indische Empire Style pada Gedung Bank Mandiri, disesuaikan dengan iklim tropis di Semarang, bentuknya didominir oleh bukaan jendela yang geometrik pada tampak depannya, porch pada pintu masuk utama (main entrance) dan juga terdapat menara di samping kiri dan kanan bangunan, untuk penyesuaian ilkim tropis dibuat galeri keliling bangunan untuk menghindari sinar matahari langsung serta tampias air hujan. 


\section{e. Gedung Speigel (Obyek.5)}

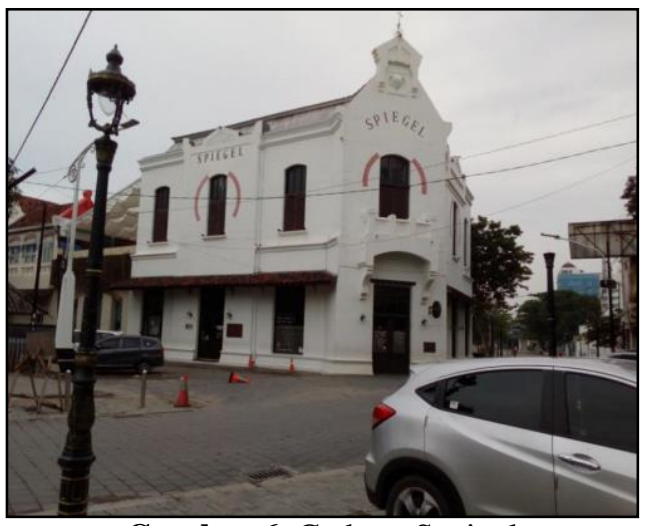

Gambar 6. Gedung Speigel

Gedung Der Speigel, berfungsi sebagai Bar \& Bistro di lantai 1 dan Impala Co Working Space di lantai 2 dengan kondisi fisik bangunan terpelihara dengan baik, sehingga Fasade bangunan memberi kontribusi sangat baik pada terciptanya Streetscape yang spesifik pada koridor jalan Letjen. Suprapto. Bangunan Spiegel Bar \& Bistro merupakan bangunan sudut dengan ornamen geometrik dengan Penggunaan Gewel (gable) seperti lonceng pada tampak depan bangunan dan juga balkon didepan pintu lantai 2 dan crown balustrade pada bawah atap. Gewel (gable) adalah bagian berbentuk segitiga dari bagian akhir dinding atap_merupakan ciri khas periode colonial (Indische Empire Style).

\section{f. Gedung Perusahaan Perdagangan Indonesia (PPI) (Obyek.6)}

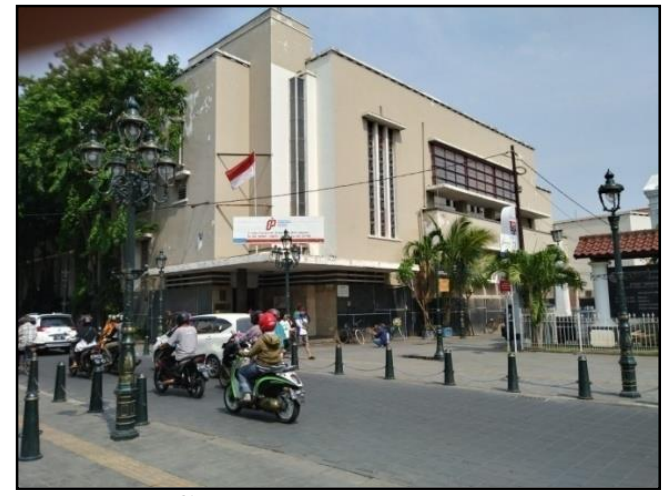

Gambar 7. Gedung PPI
Bangunan ini masih berfungsi dengan baik dan fisik bangunan terpelihara, sehingga Fasade bangunan memberi kontribusi cukup baik pada terciptanya Streetscape pada koridor jalan Letjen. Suprapto. Bangunan PT Perusahaan Perdagangan Indonesia ini dengan elemen facade yang mendominasi adalah bentuk geometrik yang sederhana dengan streamline effect horizontal dan vertical, volume bangunan yang berbentuk kubus tanpa ragam hias/ornament dengan bentuk atap datar. Desain bangunan tersebut nampak jelas mengacu pada kaidah Arsitektur modern. Desain bangunan ini fasadenya hampir mirip dengan The Town Hall at Hilversum, di Netherlands, yang dibangun oleh Willem Dudok's pada tahun 1930.

\section{g. Semarang Kreatif Galery (Obyek.7)}

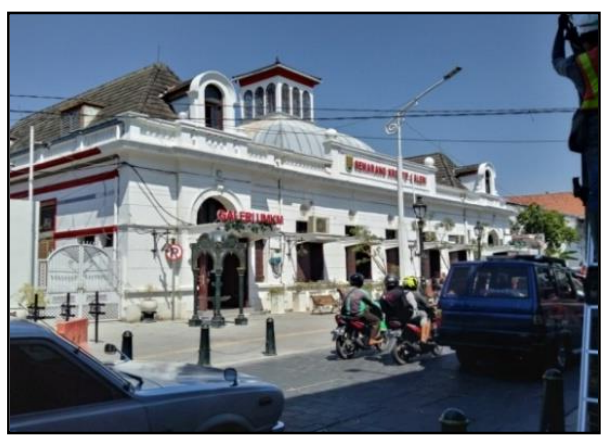

Gambar 8. Semarang Kreatif Galery

Bangunan ini dulu merupakan kantor De Javaashe Bank karya Hulswit dan Cuypers dan sekarang berfungsi sebagai Kreatif Galery dan UMKM, fisik bangunan terpelihara dengan baik, sehingga Facade bangunan tersebut memberi kontribusi cukup baik pada terciptanya Streetscape pada koridor jalan Letjen. Suprapto. Bangunan ini memiliki ornamen geometrik pada bukaan pintu yang diatasnya diberi hiasan "Vousoir" berbentuk lengkung, serta penggunaan dormer/ lucarne pada atap, namun juga terlihat pengaruh langgam lain dari ornamen porthwindow dan cantilever serta pemakaian atap perisai di tengah bangunan. Karakteristik visual langgam arsitektur pada bangunan ini ditandai dengan adanya dormer/ lucarne pada atap dan balustrade pada tepi bawah atap, ini merupakan ciri khas dari pengaruh gaya 
Arsitektur Renaissance yang dipadukan dengan ciri arsitektur Indische.

\section{h. Restoran IBC/ Ikan Bakar Cianjur} (Obyek.8)

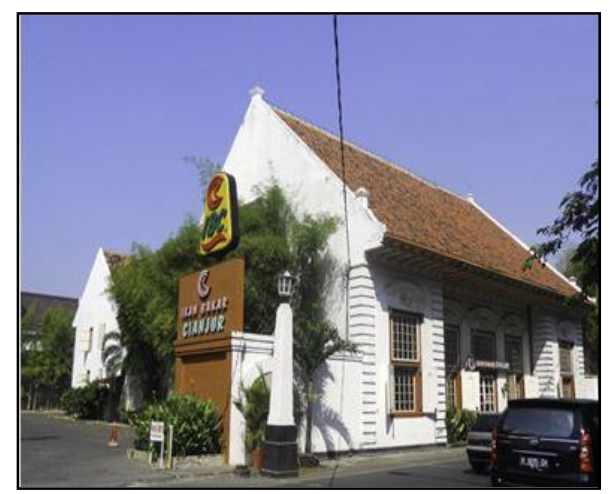

Gambar 9. Restoran IBC

Bangunan restoran Ikan Bakar Cianjur ini masih berfungsi dengan baik dan fisik bangunan terpelihara, sehingga Facade bangunan memberi kontribusi pada terciptanya Streetscape pada koridor jalan Letjen. Suprapto. Dari ciri-ciri yang nampak dapat diidentifikasi bahwa bangunan tersebut berlanggam indische. Visualisasi langgam indische pada bangunan ini adalah adanya ornamen (versening) geometric diatas pintu dan jendela, gable dan nok acroteire pada tepi/ujung atap bagian atas, pada dinding fasade terdapat pilaster dengan molding sederhana berupa garis-garis horizontal dan pengaruh bentuk arsitektur lokal pada atap berbentuk pelana. Ornamen (versening) geometric diatas pintu dan jendela pada bangunan memiliki karakter langgam art deco.

i. Gedung Kantor P.T Djakarta Lloyd (Obyek.9)

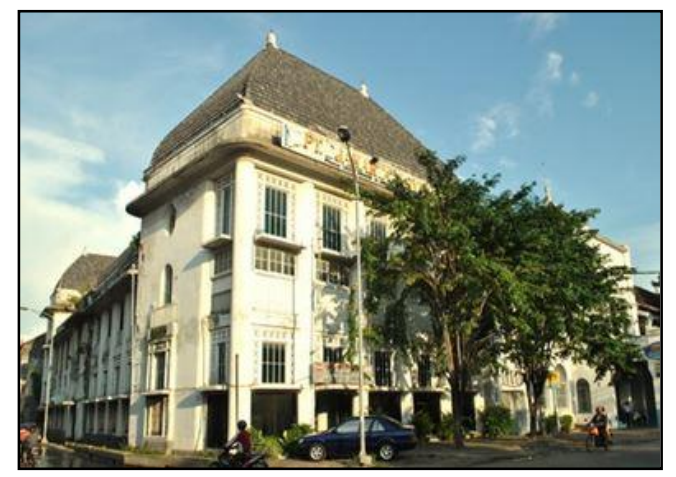

Gambar 10. Kantor Djakarta Lloyd
Bangunan Kantor Djakarta Lloyd yang terletak diujung J1. Mpu Tantular 23 Semarang, dulu merupakan bagian dari kantor pemerintah Belanda. Pada tahap awal pembangunan dilakukan pengaturan kembali batas bangunan, dimana bagian barat tapak dipotong sampai segaris dengan bangunan disebelah selatannya yaitu: Nederlandsche Handel Maatschappij. Arsitek bangunan ini adalah Thomas Karsten yang ditugasi oleh perusahaan Stoomvaart Maatschappij Nederland (SMN), sebuah perusahaan angkutan perkapalan untuk merancang bangunan kantor cabangnya di Jawa pada tahun 1930. Bangunan ini berfacade tunggal. Jumlah trafe pada tampak barat 5 dan pada tampak utara 14 dengan modul utama 3.00 meter. Bangunan berlantai 2 tetapi ada bagian yang berlantai tiga. Atap bangunan berbentuk limas mansard (model atap Belanda). Bahan penutup atapnya genteng yang didatangkan khusus dari Negeri Belanda. Lebar teritisan 2.00 meter dengan listplank dari beton selebar 1.00 meter. Pada sisi utara dan barat terdapat serambi, masing-masing selebar 3.00 meter dan 2,40 meter. Dalam bentuk aslinya serambi ini terbuka dan hanya diberi langkan, tetapi sekarang sebagian telah ditutup untuk ruangan kantor. Bangunan ini sekarang masih berfungsi dengan baik dan fisik bangunan terpelihara, sehingga Facade bangunan memberi kontribusi pada terciptanya Streetscape pada koridor jalan Mpu Tantular. Bentuk atap dengan kemiringan yang tajam untuk mengadaptasi kondisi iklim, adanya kantilever pada jendela dan pintu dengan bentuk-bentuk geometri yang menghiasi facade bangunan.

\section{KESIMPULAN}

Kawasan kota lama Semarang yang memiliki potensi atraksi wisata berupa bangunan bersejarah (heritage) dengan perpaduan gaya Arsitektur Eropa klasik terutama pengaruh Renaissance dengan unsur lokal untuk mengadaptasi dengan iklim tropis di kota Semarang. Gereja Blenduk/ Imanuel merupakan tengeran/ landmark yang berada di tengah koridor jalan Letjen. Suprapto dengan massa bangunannya yang simetris serta tampilan fasade bangunan yang kokoh melalui pilar-pilarnya yang bergaya Ionic. Tampilan 
Façade bangunan seperti ini menjadikan gereja Blenduk/ Imanuel sebagai Icon kawasan kota lama Semarang dengan penampilan Arsitektur bergaya Psedo Baroque. Dari hasil penelitian ini dapat disimpulkan bahwa daya tarik visual yang kuat pada kawasan kota lama Semarang merupakan tampilan visual dari bangunanbangunan yang memiliki gaya arsitektur yang bercorak Indische Empire Style, dengan ciri/ karakter spesifik yaitu: memiliki ornamen (cornice/molding) pada dinding dan kolom, gavel dan nok acroteire, serta sebagian mengadopsi gaya Arsitektur renaissance dengan menggunakan dormer/ lucarne pada atap. Sedangkan bangunan yang memakai gavel/gewel dan nok acroteire (bagian berbentuk segitiga dari bagian akhir dinding atap) merupakan ciri khas gaya Arsitektur Indische Empire Style.

Dari hasil analisa persepsi responden berkaitan dengan kemenarikan obyek visual berupa bangunan 1 sampai 9 (obyek 1-9) menunjukkan bahwa kekuatan daya tarik wisata dimiliki oleh bangunan-bangunan yang mempunyai gaya Arsitektur Eropa klasik terutama Arsitektur Renaissance dan Baroq, namun ada juga yang sudah dipadukan dengan unsur- unsur lokal untuk mengadaptasi terhadap iklim tropis di kota Semarang (Indische Empire Style). Skore penilaian responden terhadap kemenarikan obyek visual tersebut mencapai angka $75 \%$, sehingga dapat "disimpulkan bahwa gaya Arsitektur bangunan di kawasan kota lama Semarang sangat berpengaruh terhadap daya tarik wisata, terutama yang memiliki unsur gaya Arsitektur Eropa klasik, Renaissance-Baroq dan perpaduan dengan unsur local yaitu Indische Empire Style".

\section{REFERENSI}

BAPPEDA, 1988 : Konservasi Bangunan dan Lingkungan Kotamadya Dati II Semarang, Laporan Draft Final.

Brannen Julia, 1996 : Memadu Metode Penelitian Kualitatif \& Kuantitatif, Terjemahan, Fakultas Tarbiyah IAIN Antasari Samarinda bekerjasama dengan Pustaka Pelajar Glagah UH IV/343 Yogyakarta.

Budihardjo Eko, 1997: Kelestarian dan Pelestarian Arsitektur Indis, Makalah seminar Pelestarian dan Pemanfaatan Bangunan Indis, Yogyakarta.

Cullen Gordon, 1961 : Townscape , The Architectural Press, London.

Handinoto (1992), Perkembangan Kota dan Arsitektur Kolonial Belanda di Surabaya 1870-1940, Laporan Penelitian Universitas Kristen Petra Surabaya.

I.B.G. Pujaastawa I Nyoman Ariana, 2015, Pedoman Identifikasi Potensi Daya Tarik Wisata, Pustaka Larasan Jalan Tunggul Ametung IIIA/11B Denpasar, Bali

Muhadjir, N. 2000, Metodologi Penelitian Kualitatif. Rake Sarasin, Yogyakarta

Miles Matthew B, Huberman A. Michael, 1992: Analisis Data Kualitatif, Universitas Indinesia (UI-Press)

Pitana, I G., Gayatri, PG. 2005: Sosiologi Pariwisata. Penerbit Andi Yogyakarta.

Slamet. Y, 1993: Analisis Kuantitatif Untuk Data Sosial, Dabara Publisher, Adisucipto 68 Solo 57143.

Soekiman, Djoko, 2000. Kebudayaan Indis dan Gaya Hidup Masyarakat Pendukungnya di Jawa (Abad XVIII Medio Abad XX). Yayasan Bentang Budaya. Yogyakarta.

Sumalyo Yulianto, 1988: Arssitektur Kolonial Belanda Di Indonesia, Gajah Mada University Press. 